$\Leftrightarrow \Leftrightarrow \Leftrightarrow \Leftrightarrow$

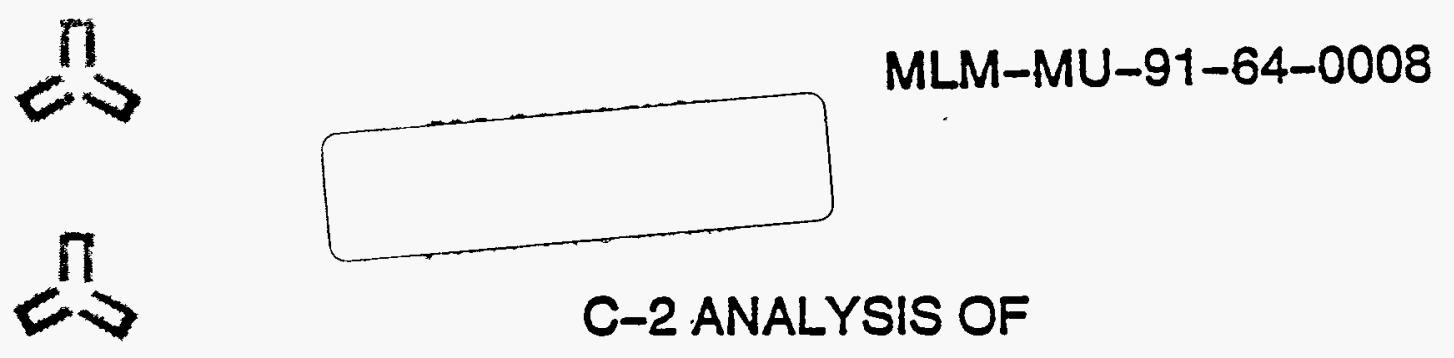

THE ENVIRONMENTAL EFFECTS

OF THE

$\lessdot \gg$ NUCLEAR FACILITIES MODERNIZATION PROJECT<smiles>C1=CC=C1</smiles>

$\lim _{\infty}$

$$
\begin{aligned}
& \text { PECENED } \\
& \text { JUL O } 1995 \\
& \text { OSTI }
\end{aligned}
$$

$\lim _{2}$

APRIL 1991

¿\EGRE MOUND APPLIED TECHNOLOGIES

P.O.BOX 3000

MIAMISBURG, OHIO 45343-3000

$513-865-4020$

operated for the UNITED STATES DEPARTMENT OF ENERGY

Contract No. DE-AC04-88-DP43495

IMASTER 


\section{2 ANALYSIS \\ OF \\ THE ENVIRONMENTAL EFFECTS OF \\ NUCLEAR FACILITIES MODERNIZATION PROJECT}

APRII 1991

\section{DISCLAIMER}

This report was prepared as an account of work sponsored by an agency of the United States Government. Neither the United States Government nor any agency thereof, nor any of their employees, makes any warranty, express or implied, or assumes any legal liability or responsibility for the accuracy, completeness, or usefulness of any information, apparatus, product, or process disclosed, or represents that its use would not infringe privately owned rights. Reference herein to any specific commercial product, process, or service by trade name, trademark, manufacturer, or otherwise does not necessarily constitute or imply its endorsement, recommendation, or favoring by the United States Government or any agency thereof. The views and opinions of authors expressed herein do not necessarily state or reflect those of the United States Government or any agency thereof. 


\section{DISCLAIMER}

Portions of this document may be illegible in electronic image products. Images are produced from the best available original document. 
1. BACKGROUND AND PURPOSE ................ 1 1.1 BACKGROUND ................... 1

1.2 PURPOSE .................... 2

2. DESCRIPTION OF THE PROPOSED ACTION AND ALTERNATIVE ACTIONS • • • • • • • • • • • • • • • • • • • • • •

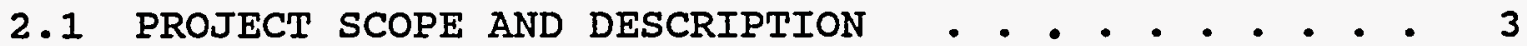

2.2 ALTERNATIVE ACTIONS . . . . . . . . . . . . . . . 7

3. POTENTIAL ENVIRONMENTAL IMPACTS OF THE PROPOSED ACTION -8

3.1 AIRBORNE TRITIUM RELEASES . . . . . . . . . . . . 11

3.2 WATERBORNE TRITIUM RELEASES . . . . . . . . . . . 15

3.3 TRITIATED WASTES ................. . 15

3.4 NON-RADIOACTIVE RELEASES AND WASTES . . . . . . . 16

3.5 PUBLIC HEALTH EFFECTS . . . . . . . . . . . . 16

3.6 WORKER HEALTH EFFECTS . . . . . . . . . . . . . 17

3.7 CONSTRUCTION AND DEMOLITION . . . . . . . . . . . 19

3.8 CUMULATIVE IMPACTS . . . . . . . . . . . . . . 20

4. SUMMARY AND CONCLUSIONS . . . . . . . . . . 21

5. REFERENCES . . . . . . . . . . . . . . 22

LIST OF FIGURES

Page

Figure 2-1. Site plan of Mound, detailing Buildings $R$ and $S W$ (SW/R Tritium Complex) and $T$ Building, location of this project. . . . . . . . . . . . . 4

\section{LIST OF TABLES}

Page

Table 3-1. Comparison of potential environmental impacts related to Mound tritium operations . . . . . 9 


\section{BACKGROUND AND PURPOSE}

\subsection{BACKGROUND}

During the past several years, the U.S. Department of Energy (DOE) weapons program workload at Mound has changed significantly due to new weapons design concepts and continued technological advances. The changes in the weapons program workload have significantly challenged the capabilities of existing nuclear laboratory buildings, including the Process Engineering/Process Development (PE/PD) laboratory operations areas located in the Semi-Works/Research (SW/R) Tritium Complex, as more emphasis is placed on utilizing state-of-the-art technologies. The PE/PD laboratory operations directly support the production of new types of tritium-based systems, which have been identified as Kyle-type systems. The introduction of activities associated with the production of Kyle systems has led to considerable changes in the PE/PD laboratory operations and serious overcrowding within the SW/R Tritium Complex. The PE/PD activities are being performed in laboratory areas which are technically obsolete. consequently there is difficulty in meeting many of the performance specifications necessary for present development component standards.

The Nuclear Facilities Modernization (NFM) line item project, which is a part of the DOE Facilities Capability Assurance Program (FCAP), will relocate the PE/PD activities from the SW/R Tritium Complex to modern laboratory areas to be constructed within the Technical (T) Building. The objectives of the NFM project are twofold: (1) replacement of a technically obsolete laboratory with a modern laboratory capable of meeting existing and future weapons programs needs, and (2) provision of a nuclear materials laboratory in which tritium system safety meets current and expected future standards. Achievement of these objectives will provide the Albuquerque Weapons Complex with a modern, versatile laboratory positioned to develop, engineer, produce, and test all current and anticipated future technologies while controlling radioactivity in accordance with modern "as low as reasonably achievable" (ALARA) guidelines.

In the early 1970's, Mound's management identified the need to reduce the levels of tritium emissions from Mound's tritium facilities. A management goal was established to reduce the level of tritium emissions through the use of management controls as well as the replacement and upgrade of the existing tritium systems. Following the establishment and implementation of management controls, a comprehensive upgrading program was initiated which systematically replaced oldex, technically obsolete systems by utilizing state-of-the-art technologies. As a result of Mound's efforts, the tritium effluents have been held at decreased levels despite increased inventory. The current emphasis is focused on 
the following two specific areas: (1) reduction of the potential for accidental releases and their associated impacts and (2) provision of the latest technology in protection for Mound's employees.

Secretary Watkins recently expressed concern about DOE's tritium facilities; and has established a task group to review facility design, operational procedures, and management practices (February 19, 1991). The Secretary's initiative further emphasizes the need to proceed with the improvements described by this project.

\subsection{PURPOSE}

The Final Environmental Impact statement (FEIS) for Mound (1), issued June 1979, evaluated the impact of the tritium operations during conditions of normal operation and estimated the potential impact of a bounding credible accident, as well as the impact of non-radioactive releases from plant-wide operations. Subsequent to the issuance of the FEIS, several program additions and/or changes to tritium operations, including the introduction of tritium operations in the $T$ Building, occurred which affected the estimated accidental releases from Mound. In 1985, the incremental impacts of the tritium systems which had been recently constructed, as well as future $T$ Building tritium operations were analyzed in the "Treatise on the Environmental Impact Resulting from Mound's Technical (T) Building Tritium operations" (2) (1985 NEPA Analysis) which was prepared to provide an analysis similar to that performed by this C.2 Analysis. Chapter 3 of this C.2 Analysis presents a comparison of the potential environmental impacts associated with current/projected Mound tritium operations, which include the NFM project, to those impacts cited in the FEIS and 1985 NEPA Analysis.

The information contained in the 1985 NEPA Analysis formed the basis for the Memorandum to File (MTF) issued July 3, $1985^{(3)}$ which documented the determination that no additional National Environmental Policy Act (NEPA) documentation would be required for the proposed projects. In March 1990, Mound was directed, by DOE/AL, to submit an Environmental Checklist for the proposed project. The subsequent review concluded that the current proposal was encompassed by the evaluation performed in 1985. However, because the project was not scheduled to begin construction until late FY-90; it was believed to be prudent to reanalyze the impacts of the NFM project with respect to the analysis of the FEIS and 1985 NEPA Analysis, to determine if there have been any significant changes over the past 5 years. This C.2 Analysis is being performed to support a DOE determination as to whether earlier NEPA documentation should be supplemented. This analysis is prepared in accordance with DOE National Environmental Policy Act (NEPA) Guidelines, 52 FR 47662, Section C.2, and Council on Environmental quality (CEQ) regulations (40 CFR 1502.9). 


\section{DESCRIPTION OF THE PROPOSED ACTION AND ALTERNATIVE ACTIONS}

\subsection{PROJECT SCOPE AND DESCRIPTION}

The NFM line item project will upgrade currently vacant laboratory areas in the $T$ Building to meet current standards for radioactive material confinement, security, and environmental protection; install new PE/PD operations (approximately 378 linear feet of glovebox line total) in the upgraded $T$ Building laboratory areas; and remove obsolete laboratory equipment from the SW/R Tritium Complex (Figure 2-1). The completion of the project will allow the PE/PD laboratory operations to conduct their assignments efficiently and will fully meet standards for radioactive materials handling. The project will also release usable laboratory space, capable of handling tritium materials, for utilization by other tritium operations within the SW/R Tritium complex. Because all construction activities associated with the project will occur within the $T$ Building and the $S W$ Building, the project is considered to be a modification to existing facilities.

The NFM project can logically be divided into the following three distinct phases: (1) upgrade of $T$ Building laboratory areas, (2) installation of laboratory equipment in upgraded $T$ Building areas, and (3) decommissioning of the corresponding laboratory equipment in the SW/R Tritium Complex area. The project, as structured, consists of the following subprojects, four of which are associated with the installation of laboratory equipment to replace obsolete equipment:

a. Upgrade of $T$ Building areas;

b. Installation of Tritium Processing, Testing, and Analysis Systems;

c. Installation of Materials Preparation and Characterization Systems;

d. Installation of Historical Materials studies Systems;

e. Installation of Component Fabrications Systems; and

f. Decommissioning of PE/PD Laboratory Operations within SW/R Tritium Complex.

A brief description of each of these subprojects follows.

- T Building Upgrade - This subproject will renovate a number of rooms on the second floor (operating level) of the $T$ Building which are currently used for office support, storage, and benchtop laboratory functions (rooms $T 218,226,227,229,230,244$ through $260,270,305,306,312,313$, and 314). A total of approximately $15,200 \mathrm{ft}^{2}$ will be renovated $\left(8,000 \mathrm{ft}^{2}\right.$ designated as laboratory space; 7,200 $\mathrm{ft}^{2}$, support space). In order for 




Figure 2-1. Site plan of Mound, detailing Buildings $R$ and SW (SW/R Tritium Complex) and $T$ Building, location of this project. 
these rooms to be transformed into PE/PD laboratory operations areas, major modifications to the room heating, ventilation and air conditioning (HVAC) and electrical systems will be required. The walls will be epoxy painted for ease of cleaning and decontamination and the doors will incorporate special seals aiding room radioactive materials confinement. other utility service headers such as cooling water, nitrogen, argon, helium, and compressed air will be distributed in the rooms as needed. The $T$ Building Upgrade subproject will also include the renovation and extension of the first floor utilities required for the proposed second floor operations areas. The major areas of modification will be the HVAC systems, the installation of a process cooling water loop, and the installation of a new double-ended electrical substation.

- Tritium Processing, Testing, and Analysis Systems - This subproject will include relocating the Function Testing activities from rooms SW 142 and SW 150 to $T$ 257. These activities provide the testing capabilities for various $P E / P D$ experiments used in product development and evaluation. New equipment will be installed including glovebox purge and monitoring systems; 54 linear feet of glovebox line; as well as component loading, weighing, in-line calorimetry, and radiography equipment. A supporting mass spectrometry system, including 9 linear feet of glovebox line, will be centrally located in $T 260^{\circ}$. The mass spectrometry system will analyze gas samples from the process and storage systems. The supporting Health Physics operations will be centrally located in $T 226$ to provide support to all second floor nuclear operations. This area will serve as the data center for room and glovebox line tritium monitors.

- Material Preparation and Characterization Systems - This subproject will include the relocation of the specimen Preparation Laboratory activities and the Characterization study activities. The Specimen Preparation Laboratory activities will be relocated from SW 150 and SW 152 to $T$ 257. These activities provide the calorimetry, assembly, and loading of various units used in the development of various development components. New equipment will include 64 linear feet of glovebox line and a high pressure gas handling system with its associated compressor. The Characterization study activities will be relocated from $S W 13$ and $S W 152$ to $T 259$ and will require approximately 32 linear feet of glovebox line. The functions performed in this area are operations associated with the characterization of special materials. New equipment installed for this function will include constant temperature baths, ion chambers, calibrated volumes and coils, molecular sieve traps, vacuum and vane pumps, and other laboratory bench-top equipment. Hot Inert Operations activities will be relocated from SW 150 to T 259 and will require approximately 52 linear feet of glovebox line. These general activities are performed in support of the other PE/PD laboratory activities and include metallurgical 
specimen preparation, experimental device repair, gas loading of repaired experiments, and short-term experiment storage. The equipment used in these activities will consist of hand tools, precision machine tools, a gas handling system, and storage cabinets.

- Historical Materials studies Systems - This subproject will include the Gas Sampling and Storage operations. The Gas Sampling area will consist of 16 linear feet of glovebox line in T 246 housing two gas sampling collection points. The new equipment inside the glovebox line will include various volumes, valves and piping that allow gas to be transferred to various analytical and technical support functions. Sample ports will also be available for the transfer of gas into portable containers which must be physically transferred to other analytical areas. Current storage operations activities located in SW 142 and SW 238 are performed in fumehoods. New equipment will consist of environmental chambers and ovens in which longterm environmental studies under stable conditions will be performed. This equipment will be placed in approximately 99 linear feet of glovebox line in $\mathrm{T} 246$.

- Component Fabrication Systems - This subproject will include relocating activities currently located in SW 238 and R 168 into $T 218$ and $T 229$. The cold Processing activities will require approximately 14 linear feet of glovebox line. The gloveboxes will provide a high purity environment for development of different components for PE/PD testing. The new equipment required for this laboratory will include analytical equipment, a leak detector, and a helium compressor. Cold processing activities will require separate material handling gloveboxes (16 linear feet), a resistance forge welding glovebox (8 linear feet), a miscellaneous support glovebox (14 linear feet), and support fumehood space. These activities will refine the nonradioactive processes and components and will help establish production standards and requirements for future weapon component builds.

- Decommissioning of PE/PD Laboratory operations within SW/R Tritium Complex - This subproject will remove the obsolete equipment from the PE/PD laboratory operations areas located in the SW/R Tritium Complex (rooms SW 142, 150, 152, 238, and 240) and will refurbish the same areas to the extent necessary to permit utilization by other current tritium operations within the SW/R Tritium Complex. Upon completion of this subproject, approximately $6,100 \mathrm{ft}^{2}$ of usable laboratory space, capable of handling tritium materials, will be available. 


\subsection{ALTERNATIVE ACTIONS}

The following alternative actions to the proposed NFM Iine Item Project are available: (1) no-action and (2) delayed-action. This alternative action analysis was included since it would be evaluated as part of an EA or EIS.

- No-Action Alternative - This alternative would consist of not upgrading the PE/PD laboratory operations as described in the proposed project scope (Section 2.1). The "no-action" alternative would require $P E / P D$ activities to remain in their present location in the sw Building. The major benefits of the NFM project (the reduction of exposure to workers, the reduction of routine tritium releases to the environment, and the reduction of the probability and consequences of unusual occurrences) would not be realized under this alternative. Due to the age of the existing PE/PD laboratory equipment, the environmental, health, and financial risks associated with these operations would continue to increase with time.

- Delayed-Action Alternative - This alternative would consist of deferring the implementation of the proposed project. Deferring the NFM project would delay the realization of the benefits that would be derived from its implementation. Under the "delayedaction" alternative, the environmental, health, and financial risks associated with the existing PE/PD operations would remain at their current levels for a longer period of time than that anticipated under the present schedule for implementation of the NFM project. 


\section{POTENTIAL ENVIRONMENTAL IMPACTS OF THE PROPOSED ACTION}

Mound tritium operations can impact the environment by airborne releases, waterborne releases, and disposal of tritiated liquid and solid wastes. The airborne tritium releases are the primary source of tritium impact to the environment. Comparisons of the potential environmental impacts related to Mound tritium operations cited in the FEIS (1979), the 1985 NEPA Analysis, and those resulting from current/projected operations are qualitatively presented in Table 3-1 for various environmental issues. The potential impacts cited for the FEIS express whether there is a significance to the environment or to human health. The potential impacts cited for the 1985 NEPA Analysis and the current/projected operations reflect whether there are any significant changes when compared to the predecessor document(s). AnY impacts of the NFM project, noted in Table 3-1, are discussed further in this chapter.

Dose assessment methodologies, acceptable concentration and dose standards, and release reporting criteria have changed since the issuance of the FEIS. In order to make a valid comparison of the health effects associated with this analysis; all effective dose equivalents, including those presented by different methodologies in past reports, have been determined using current dose assessment methodologies ${ }^{(4)}$ and evaluated against current DOE standards ${ }^{(5)}$. 
Table 3-1. Comparison of potential environmental impacts related to Mound tritium operations

Environmental

Issue

1. Tritium Releases

\section{a. Airborne}

i. Routine Operations

ii. Bounding Credible Accident

b. Haterborne

2. Tritiated Wastes
a. Liquid
b. Solid

3. Non-radioactive Releases
a. Air

b. Water Environmental Impact 1985 HEPA Analysis (1985)

\begin{tabular}{ccc}
\multicolumn{3}{c}{ Environmental Impact } \\
\hline FEIS & 1985 NEPA & Current/Projected $^{2}$ \\
& Analysis & Operations \\
(1979) & (1985) & (1991) \\
\hline
\end{tabular}
Operations

(1979) (1991)

4. Non-radioactive Wastes
a. Liquid

b. Solid

HS

NS

NC

NC

$\mathrm{NC}^{\mathrm{C}}$
$\mathrm{NC}^{\mathrm{C}}$

5. Public Health Effects ${ }^{d}$
a. Routine Operations
b. Bounding Credible Accident

C

NC

NC

6. Worker Health Effects ${ }^{d}$

a. Routine Operations

b. Bounding Credible Accident

$\begin{array}{lll}\mathbf{c} & \mathbf{x} \\ \mathbf{c} & \mathrm{x}\end{array}$

$L^{*}$

7. Resources Expended
a. Construction
b. Demolition
c. Operations

$\begin{array}{llc}\text { NA } & \text { PS } & P S^{*} \\ \text { NA } & \text { PS } & P S^{*} \\ C & X & H^{\text {e,f }}\end{array}$

Legend/Notes:

C - Impact was identified in FEIS. Concentrations, doses, mitigative measures, or processing methods cited in FEIS Comply with appropriate regulations and standards cited in FEIS. The 1985 and 1991 documents comply with the appropriate regulations and standards enforce at the time of their respective analysis.

$L$ - Impact is Lower than that identified in proceeding document(s). Impacts that are considered to be reduced significantly are included in this category (significance of reduction is discussed in this chapter).

$H$ - Impact is Higher than that identified in proceeding document(s).

N - Impact is identified in FEIS. Concentrations or doses cited in FEIS do Not comply with appropriate regulations and standards cited in FEIS.

NA - Impacts identified in FEIS are project specific and are Not Appropriate for comparison to impacts associated with current and planned projects.

(Continued) 
Table 3-1. (Continued)

Legend/Notes (Continued):

NC - Impact represents No Change from impact identified in proceeding document(s). Incremental impacts considered to be of an insignificant magnitude are included in this category (basis for determination is provided in this chapter).

NS - site-wide impact was identified in FEIS. Concentrations, doses, mitigative measures, or processing methods cited in FEIS comply with appropriate regulations and standards cited in FEIS. The potential contribution from tritium operations to the site-wide impact has been reviewed and determined to be Mot Significant.

PS - Impact is Project Specific. Comparison against impacts identified in preceding document(s) is not appropriate.

$X$ - Issue is not addressed in document and/or data are not presented to establish basis for comparison.

* - Significant incremental impact associated with the MFM Project which is discussed further in this chapter.

${ }^{a}$ Includes impacts from all current tritium operations and from all future tritium operations in design/construction or planning phase, including NFM Project.

${ }^{b}$ All wells identified in FEIS attained compliance with current EPA standards for tritiun in primary drinking water in 1981.

Impact of routine operations. Short-term impact associated with the construction and demolition phases of the project are addressed as separate issues.

dHealth effects resulting from tritium releases cited in FEIS and/or 1985 NEPA Analysis have been calculated using current dose assessment methodologies and evaluated against current standards.

'Approximate number of employees on site is currently 2100 compared to 1700 during 1979.

'Relocation of PE/PD laboratory operations from SH/R Tritium Complex to T Building will not change manpower requirements. 


\subsection{AIRBORNE TRITIUM RELEASES}

The FEIS (1979) evaluated the impact of existing tritium operations during routine operation and accident conditions. The FEIS cited that through improvements in tritium process technology and the application of stringent administrative controls, during the eight-year period from calendar year 1970 (CY-70) through $C Y-77$, airborne tritium releases were progressively reduced from $179,400 \mathrm{Ci} / \mathrm{Yr}$ to $4,900 \mathrm{Ci} / \mathrm{Yr}$.

The FEIS assessed the impact of tritium operations at Mound through CY-77 without any projection of the impacts associated with proposed operations. There were no tritium operations in the T Building when the FEIS was issued. The 1985 NEPA Analysis was prepared to analyze the incremental impact of the tritium systems which had been recently constructed, as well as the incremental impact of future $T$ Building tritium operations on the routine airborne tritium site releases. The 1985 NEPA Analysis concluded that the $T$ Building tritium operations would result in a total incremental routine airborne tritium release of $1825 \mathrm{Ci} / \mathrm{yr}$. Using the actual airborne tritium releases from other Mound operations, the 1985 NEPA Analysis concluded that the $T$ Building operations would increase the Mound routine tritium airborne releases to a total of $5255 \mathrm{Ci} / \mathrm{yr}$, approximately 7\% greater than the lower limit cited in the FEIS.

During the ten-year period from CY-80 through CY-89, the routine airborne tritium releases from Mound averaged $7714 \mathrm{Ci} / \mathrm{Yr}$. If the single large-scale tritium release $(37,600 \mathrm{ci})$ which occurred in CY-89 is discounted, the average routine airborne tritium releases during this period would be $3954 \mathrm{Ci} / \mathrm{yr}$, approximately 75\% of the release level projected in the 1985 NEPA Analysis. When the planned tritium operations currently in the construction and/or design phases are taken into account, the projected routine airborne tritium releases from Mound tritium operations are approximately $3900 \mathrm{Ci} / \mathrm{yr}$.

- Routine operations - The NFM project will provide modern laboratory equipment incorporating significant safety-related design not found on present PE/PD equipment items. The project will also provide enhanced tritium containment. For example, the existing PE/PD operations, located in the SW/R Tritium Complex, utilize glovebox lines or fumehoods. Those operations currently performed in fumehoods have only one level of containment (i.e., the primary containment provided by the laboratory equipment itself); therefore, any leak from the primary containment will result in a release of tritium directly to the environment through the building exhaust system. In general, $\mathrm{PE} / \mathrm{PD}$ operations relocated to the $\mathrm{T}$ Building will be housed in gloveboxes which will provide secondary containment. Tritium released into a glovebox (secondary containment) will be processed through the new Tritium Emissions Reduction Facility 
(TERF) which will recover a significant portion of the tritium from the glovebox inerting gases prior to release to the environment. The modern laboratory equipment and enhanced containment to be provided under this project, as well as existing tritium recovery capabilities within the $T$ Building (i.e., TERF), will reduce routine airborne tritium releases to the environment during $\mathrm{PE} / \mathrm{PD}$ laboratory operations. The estimated airborne tritium releases projected for the $\mathrm{PE} / \mathrm{PD}$ laboratory operations in the T Building are $100 \mathrm{Ci} / \mathrm{yr}$ compared to the $500 \mathrm{Ci} / \mathrm{Yr}$ for the same operations currently conducted in the SW/R Tritium Complex. The estimated impact of the NFM project on Mound routine airborne tritium releases resulting from $\mathrm{PE} / \mathrm{PD}$ operations (400 $\mathrm{Ci} / \mathrm{Yr}$ reduction) is reflected in the $3900 \mathrm{Ci} / \mathrm{yr}$ routine airborne tritium releases estimated for current/projected Mound tritium operations.

Routine operations can also be effected by an airborne tritium release, which under current Mound reporting procedures ${ }^{(6)}$ would be reported as an unusual occurrence. Although the probability of an unusual occurrence involving an airborne tritium release is relatively low, the consequences to Mound tritium operations could be significant and far-ranging. A recent case in point is the 37,600 $\mathrm{Ci}$ release that occurred in the Component Evaluation operations (CEO) Function Test area on November 8, 1989. The release, which was the single largest in twenty years, nearly equalled the total of all tritium releases from Mound during the ten previous years and caused the ten-year average (CY-80 through (Y-89) for Mound airborne tritium releases to increase approximately 95\%, from $3954 \mathrm{Ci} / \mathrm{yr}$ to $7714 \mathrm{Ci} / \mathrm{yr}$. Although the release was clearly established to have no significant environmental or public health impacts, it nevertheless received heavy media coverage and intense public scrutiny. The incident occurred during a tritium gas transfer operation involving the use of a laser through a quartz window which shattered during the transfer operation. The operation was performed under a fumehood; therefore, once the containment afforded by the quartz window was breached, the tritium was discharged directly to the environment through the building ventilation exhaust system. As a result of this occurrence, the Function Test operation was shut down for approximately 15 months. Six man-years of production effort has been lost and approximately 40 man-years of effort by administrative, engineering, and other personnel have been expended to effect the necessary corrective action. This occurrence not only resulted in tangible production and cost impacts, but also had an adverse impact on the public perception of DOE capabilities to operate Mound in a safe manner. 
Relocation of the PE/PD operations to the $T$ Building will provide a reduction of the risk associated with these operations by reducing both the probability and consequences of unusual occurrences involving tritium releases.

- Bounding Credible Accident - The FEIS (1979) identified a breach of primary containment resulting in the release of $200,000 \mathrm{Ci}$ of tritium as the upper limit for the bounding credible accident for Mound tritium operations. The 1985 NEPA Analysis noted that the tritium operations analyzed in the FEIs did not include secondary containment features such as those incorporated into the design of $T$ Building tritium operations. The 1985 NEPA Analysis cited safety analyses ${ }^{(7)(8)}$ which indicated that, for operations within the $T$ Building, a similar breach of primary containment could result in a release of $25 \mathrm{Ci}$ of tritium to the environment. The 1985 NEPA Analysis identified a simultaneous breach of both primary and secondary containment as the bounding credible accident for the $T$ Building tritium operations. This bounding credible accident, which would have a lower probability of occurrence than a breach of a single containment, could result in a release of up to $3000 \mathrm{Ci}$ of tritium to the environment. The 1985 NEPA Analysis identified the "worst case" accident scenario as the simultaneous breach of primary, secondary, and tertiary containment; however, this scenario had been determined to be an incredible event (probability less than $10^{-6}$ events per year). The 1985 NEPA Analysis concluded that, because the design of $T$ Building tritium operations incorporated modern engineered safety features, the accident analyses for these operations have shown that they have a lower probability of occurrence and less potential environmental impact than the bounding credible accident presented in the FEIS.

The most recent safety analysis of tritium operations in the SW/R Tritium Complex ${ }^{(9)}$ established a release of $50,000 \mathrm{Ci}$ of tritium to the environment as the upper limit for the bounding credible accident for Mound tritium operations outside $T$ Building. A credible accident involving the current $P E / P D$ laboratory operations in the SW/R Tritium Complex could conceivably result in a release up to this $50,000 \mathrm{Ci}$ limit. Based on a recently performed safety analysis of the proposed $\mathrm{PE} / \mathrm{PD}$ operations in the new NFM laboratories in T Building, (10) no credible event could occur which would result in a tritium release to the environment of this magnitude. The extensive safety features, systems, and administrative controls which are a part of the NFM project are specifically designed to reduce the probable occurrence and potential quantity (and thus the risk) of tritium released from the PE/PD laboratory operations in the $T$ Building. Credible quantities of tritium released from the PE/PD laboratory operations in the $T$ Building will be well within the $3000 \mathrm{Ci}$ limit release established for the bounding 
credible accident associated with existing $T$ Building tritium operations.

The most severe accident scenario in the PE/PD operations would be a fire involving a single or double tritium containment in which the containment is breached and a mixture of tritium/tritium oxide is released into the laboratory area. For the PE/PD laboratory operations in the SW/R Tritium Complex, this is a credible accident scenario. Because there is no containment beyond the glovebox (secondary containment), releases into the laboratory areas are discharged directly to the environment. The safety analysis performed for the proposed $\mathrm{PE} / \mathrm{PD}$ laboratory operations in the $\mathrm{T}$ Building has determined this to be an incredible event. The NFM project design has emphasized the prevention of fire events by the inclusion of fire resistant materials in the construction of the $P E / P D$ laboratory and equipment and has provided for extensive fire detection and suppression systems within the laboratory areas. Even if such an event could occur, those PE/PD laboratory rooms in the $T$ Building having the greatest potential for tritium releases will be protected by the existing Emergency Containment System (ECS). The ECS will be utilized to provide tertiary containment by isolating the affected laboratory room(s) and removing up to $90 \%$ of the tritium oxide from the laboratory room exhaust prior to its release to the environment. Because the radiological hazard of tritium oxide is several orders of magnitude greater than elemental tritium, the availability of the ECS tritium oxide removal capabilities are especially important during an occurrence (such as a fire) in which a significant quantity of tritium oxide is generated concurrent with the release.

While the current risk associated with performing $P E / P D$ laboratory activities in the SW/R Tritium Complex is considered to be relatively low, the risk is dependent on the low probability of accident events, strong administrative controls, and highly trained laboratory personnel. The PE/PD laboratory operations conducted in the $T$ Building will not only rely on these factors, but will also place more reliance on engineered safety aspects and stronger mitigative features. Additionally, the T Building's hardened construction and placement below grade enhances its resistance to the effects of natural phenomena over that of the sw Building.

There has not been a significant reduction in the tritium inventory at Mound since the FEIS was issued; however, due to operational and procedural improvements previously noted, the upper limit of the tritium that would be released during a bounding credible accident has been reduced. Although the NFM project will reduce the probable quantity of tritium released during a bounding credible accident, the major contribution of the project towards reduction of the risk involving the PE/PD 
laboratory operations is the significantly lower probability of occurrence for such an event.

\section{3 .2 WATERBORNE TRITIUM RELEASES}

The FEIS (1979) cited that during the period from $C Y-70$ through $\mathrm{CY}-77$, the estimated waterborne tritium releases from Mound were reduced from a peak of approximately $370 \mathrm{Ci}$ during $\mathrm{CY}-71$ to $40 \mathrm{Ci}$ during $\mathrm{CY}-77$. The maximum tritium concentration measured in off-site wells during $\mathrm{CY}-77$ was $47 \mathrm{nCi} / \mathrm{L}$ which is approximately 233\% of the current acceptable Environmental Protection Agency (EPA) concentration for drinking water $(20 \mathrm{nCi} / \mathrm{L}$ per $40 \mathrm{CFR} 141$, Subpart B, issued July 1976). The FEIs discussed the reasons for tritium concentrations in the local wells and identified actions taken to reduce the levels. As a result of the identified actions and continued reduction of waterborne tritium releases, all but one of the off-site wells were in compliance by 1978 and all wells were in compliance by 1981 .

Mound tritium operations do not routinely release any tritium by waterborne pathway that is greater than $20 \mathrm{nci} / \mathrm{L}$, compared to DOE Order 5400.5 release criteria which is $2000 \mathrm{nCi} / \mathrm{L}$. Total waterborne tritium releases from Mound during $\mathrm{cY}-89$ were $5.66 \mathrm{Ci}$ and the maximum tritium concentration measured in off-site wells during CY-89 was $5.2 \mathrm{nCi} / \mathrm{I}$, approximately $26 \%$ of current acceptable EPA concentration for drinking water.

Relocation of the PE/PD laboratory operations to the T Building will have no significant incremental impact on the current/projected level of waterborne tritium releases.

\subsection{TRITIATED WASTES}

The solid and liquid tritiated wastes generated by the PE/PD laboratory operations constitute a relatively small fraction of the total solid and liquid tritiated waste volumes generated by Mound tritium operations. The liquid wastes are solidified, mixed with solid wastes and packaged for off-site disposal as low specific activity (LSA) waste.

The PE/PD operations have generated approximately $2450 \mathrm{ft}^{3} / \mathrm{Yr}$ or $20 \%$ of the average tritiated waste generated by the SW/R Complex $\left(12,250 \mathrm{ft}^{3} / \mathrm{Yr}\right)$ over the past 10 years. Relocation of the PE/PD laboratory operations to the $T$ Building will have no significant incremental impact on the current/projected volumes of solid and liquid tritiated waste generated by these operations. 


\subsection{NON-RADIOACTIVE RELEASES AND WASTES}

Mound tritium operations do not contribute significantly to the site-wide non-radioactive airborne emissions or to the nonradioactive pollutants present in effluent waters. The small volumes of non-radioactive liquids and solids generated by Mound tritium operations do not contribute significantly to the total volumes generated site-wide. The relocation of the PE/PD laboratory operations to the $T$ Building will have no significant incremental impact on the discharge of non-radioactive pollutants or the generation of non-radioactive waste volumes.

\subsection{PUBLIC HEALTH EFFECTS}

Implementation of the NFM project will not adversely impact public health. In fact, the project is expected to reduce the risk of potential radiation exposure to the general public resulting from the large scale tritium release that could be associated with a bounding credible accident.

- Routine operations - Using current dose assessment methodologies, the CY-77 tritium releases would have been expected to result in an effective dose equivalent (EDE, as defined in DOE Order 5400.5) for the maximally exposed individual off site of 0.02 mrem EDE for airborne releases and 1.60 mrem EDE for waterborne releases for a total estimated dose of 1.62 mrem EDE. The 0.02 mrem EDE resulting from the CY-77 airborne tritium releases represents approximately $0.2 \%$ of the EPA air emissions standard of $10 \mathrm{mrem} / \mathrm{Yr}$ EDE (40 CFR 61, Subpart H). The total estimated dose of $1.62 \mathrm{mrem}$ EDE from air and water represents approximately $1.6 \%$ of the current DOE standard for prolonged exposure to any member of the public $100 \mathrm{mrem} / \mathrm{yr}$ EDE (per DOE Order 5400.5).

Although the NFM project will reduce the estimated routine airborne tritium releases from the PE/PD laboratory operations, the environmental and public health impacts of routine tritium releases have been determined to be insignificant. Based on CY-89 environmental monitoring data(11), the maximum dose to an individual from tritium stack emissions was $0.02 \mathrm{mrem}$ EDE, $0.2 \%$ of the EPA air emissions standard and $0.02 \%$ of the DOE standard. During CY-89, the calculated dose to the maximally exposed individual off site resulting from the maximum measured tritium oxide concentration from all pathways (air, water, and foodstuffs) was 0.4 mrem EDE, $0.4 \%$ of the current DOE standard. The anticipated dose resulting from current/projected routine tritium operations is estimated to be $0.02 \mathrm{mrem} / \mathrm{Yr}$ EDE, when adjusted for the CY-89 CEO release; well within the limits set by the conditions analyzed by the FEIS.

The risk to public health resulting from an unusual occurrence, except in the most extreme cases (i.e., bounding credible 
accidents), is low. The $37,600 \mathrm{Ci}$ release that occurred in the CEO area during $\mathrm{CY}-89$ (Section 3.1 ) resulted in a measured maximum off-site tritium oxide concentration equal to approximately $0.004 \%$ of the DOE DCG and a calculated dose to the maximally exposed individual off site of 0.001 mrem EDE.

- Bounding Credible Accident - Based on current dose assessment methodologies and assuming exposure to elemental tritium, the $200,000 \mathrm{Ci}$ release for the bounding credible accident cited in the FEIS would result in an estimated dose to the maximally exposed individual off site of $0.006 \mathrm{mrem}$ EDE. If this release were accompanied by a fire, a larger portion of the tritium released would be converted to tritium oxide and the dose to the maximally exposed individual could be as high as 51 mrem EDE. By comparison, the $50,000 \mathrm{Ci}$ tritium release identified in the SW/R Tritium Complex safety analysis would result in an estimated dose' to the maximally exposed individual off site ranging from a minimum of 0.0035 mrem EDE, assuming the release is elemental tritium, up to a maximum of 10 mrem EDE, assuming some portion of the release were tritium oxide. This range of exposure for current Mound tritium operations outside the $T$ Building is well within the limits set by the conditions analyzed in the FEIS. When the credible accidental tritium releases to the environment for the $\mathrm{PE} / \mathrm{PD}$ laboratory operations in the $\mathrm{T}$ Building (less than $3000 \mathrm{Ci}$ - Section 3.1) are compared to the current $P E / P D$ laboratory operations in the $S W / R$ Tritium Complex, the potential impact of the NFM project to the public health will be significantly less.

\subsection{WORKER HEALTH EFFECTS}

One expected impact of the NFM project will be the reduction of potential radiation exposure to workers. This will result from the replacement of older laboratory equipment with modern tritium containment systems and less handling of contaminated items during maintenance operations.

The modern laboratory equipment to be provided by the project will reduce the handling of items contaminated with tritium oxide, which is about 25,000 times more radiotoxic than elemental tritium gas. Historically, maintenance and decontamination of tritium laboratory equipment are the routine operations most likely to result in significant operator exposure to tritium oxide. Specific features are provided in the PE/PD laboratory equipment design that provide secondary containment of spent pump oil transfer and decontamination operations. In effect, the NFM design replaces personal protective equipment and fumehood breathing zone protection with tritium monitored glovebox protection. In general, worker exposure to tritium oxide contamination during equipment maintenance is the residual risk of operating a tritium laboratory; serious exposure could occur if procedures are not carefully followed. Present worker exposures have been maintained at an 
acceptable level through administrative and procedural controls and by the reliance on a highly trained work force. The new PE/PD laboratory equipment design will further reduce the probability of worker exposure during routine operations. The anticipated reduction in worker exposure may be demonstrated through comparison of recent occupational tritium EDEs for workers in the PE/PD laboratory area in the SW/R Tritium Complex to the EDEs for workers in the Kyle production area in the $\mathrm{T}$ Building. The Kyle production area, which handles larger quantities of tritium than the PE/PD laboratory and which has approximately the same number of personnel, incorporates much of the same basic design criteria applied to the NFM project. It is expected that, with the same level of tritium handling and containment technology, the new PE/PD laboratory operations will result in worker exposures comparable to those experienced in the Kyle production area. During the two-year period from $\mathrm{CY}-87$ to $\mathrm{CY}-88$, the integrated dose received by $\mathrm{PE} / \mathrm{PD}$ laboratory personnel (1378 mrem EDE) was 29.4\% of the total Mound tritium dose; while the integrated dose received by Kyle production personnel $(29.6 \mathrm{mrem}$ EDE) was $0.63 \%$ of the total Mound tritium dose(12,13), approximately $2 \%$ of the exposure received by PE/PD laboratory personnel. From the above comparison it is reasonable to expect that worker exposures associated with the new PD/PE laboratory operations will be 5\%, or less, of those experienced with the current PE/PD laboratory operations.

The potential radiation exposure resulting from an unusual occurrence, represents a more significant health risk to workers than to the general public (Section 3.5). Such an event could be connected with a large scale release of tritium/tritium oxide into confined laboratory spaces in which significant concentrations could accumulate before dilution is affected through removal and/or release to the environment. Following the event, decontamination and maintenance activities required to return the affected operation to standby/operational status would result in additional worker exposure. The anticipated reduction of impact on operating personnel caused by an unusual occurrence can be demonstrated by a comparison of the summary risk tables of the final safety analysis report for the SW/R Tritium Complex ${ }^{(9)}$ and the preliminary safety analysis report for the NFM project.(10) It is expected that the use of the new laboratory systems, including the improved laser system, tritium confinement, and gas handling system design, will reduce the probability of significant health impact by about a factor of 10 . 


\subsection{CONSTRUCTION AND DEMOLITION}

The impacts of the construction and demolition phases of the NFM project will be short-term and project-specific in nature. No attempt has been made to compare these project-specific impacts to those cited in the FEIS or 1985 NEPA Analysis.

The construction and demolition activities associated with the NFM project are limited to the interiors of the $T$ Building and the SW Building and, as such, are considered to be modifications to existing facilities. These project phases will have little impact on the environment of the site or the surrounding area. The project will not involve the use of surrounding land; nor will any project activities result in impacts upon local historical landmarks, floodplain or wetland areas, or threatened and endangered species.

All construction and demolition activities associated with the project will be controlled, as required, to conform with the Mound Loss Prevention and Environmental Control (LP\&EC) System(14) requirements which govern Mound environmental, safety, and health programs. IP\&EC System requirements include design and construction reviews by the various IP\&EC functions, including safety, industrial hygiene, fire protection, and health physics. All activities will be accomplished under the policies and procedures currently in effect at the Mound site in compliance with applicable codes and regulations.

- T Building Upgrade - This subproject, previously detailed in Chapter 2, will be accomplished within areas of the $T$ Building. The only activity associated with this subproject that will require extraordinary regulatory action is the replacement of the two existing substations because the transformers contain PCBS. The PCB contaminated transformer oil will be removed and transferred for disposal in accordance with applicable environmental regulations. Air emissions and liquid waste discharges from the construction activities within the $T$ Building will be inconsequential. Solid wastes generated by this subproject are estimated to consist of $20,800 \mathrm{ft}^{3}$ of construction debris and $10,300 \mathrm{ft}^{3}$ of salvageable materials, including existing equipment to be removed, which will be recycled to the maximum extent practical. The incremental increase in solid waste from the $\mathrm{T}$ Building Upgrade project will not adversely affect the capacity of Mound's solid waste processing capabilities.

- Decommissioning of PE/PD Laboratory operations within $S W / R$ Tritium Complex - This subproject, previously described in Chapter 2, will be accomplished within areas of the sw Building currently occupied by the PE/PD laboratory operations. The obsolete tritium laboratory equipment to be removed will be decontaminated to a level which will permit it to be 
disassembled and packaged in DOT-approved containers for transport to a DOE-approved burial site as ISA waste. Refurbishment of the vacated areas will include partial decontamination of the areas to the extent required to permit occupancy by other operations currently located in the SW/R Tritium Complex. Radioactive air emissions associated with this subject are estimated to be $500 \mathrm{Ci}$, while nonradiological air emissions will be inconsequential. Liquid waste solutions resulting from equipment and building decontamination will be collected, solidified, and packaged for off-site disposal. Nonradioactive liquid waste discharges resulting from the construction activities will be inconsequential. Solid radioactive waste generated by the equipment removal and decontamination activities in the SW Building are estimated to be $10,000 \mathrm{ft}^{3}$ or approximately $10 \%$ of the average radioactive construction waste $\left(100,000 \mathrm{ft}^{3} / \mathrm{Yr}\right)$ which has been generated by Mound over the past 10 years. The incremental increase in solid and liquid wastes from the SW/R Tritium Complex Decommissioning subproject will not adversely affect the capacity of Mound's waste processing capabilities.

\subsection{CUMULATIVE IMPACTS}

The modernization and relocation of the PE/PD laboratory operations under the proposed action will not adversely impact human health or the environment. Because the incremental impacts of the proposed action are negligible, no significant cumulative adverse impacts would be expected from the proposed action in combination with other existing or planned operations at Mound.

The proposed action will reduce the routine airborne tritium releases from the $\mathrm{PE} / \mathrm{PD}$ laboratory operations from $500 \mathrm{Ci} / \mathrm{Yr}$ to $100 \mathrm{ci} / \mathrm{yr}$. The $100 \mathrm{Ci} / \mathrm{yr}$ release is approximately $3.6 \%$ of the total routine airborne tritium releases from current/projected Mound tritium operations. The incremental increase in background radiation contributed by the proposed action would total approximately 0.3 person-rem EDE annually, which is $0.00003 \%$ of the estimated 1,000,000 person-rem EDE received annually from natural background radiation by the population within 50 miles $(80 \mathrm{~km})$ of Mound. 


\section{SUMMARY AND CONCLUSIONS}

This analysis indicates that the potential impacts associated with the current/projected Mound tritium operations are adequately bounded by the existing environmental impacts analyzed in the FEIS. It also indicates that the incremental impacts of the NFM project will make a positive contribution to the overall impact of current/projected tritium operations.

Except for minor and normal temporary conditions during the construction and demolition phases, the NFM project would measurably reduce the likelihood of adverse consequences to the environment. Relocation of the $\mathrm{PE} / \mathrm{PD}$ laboratory operations from the SW/R Tritium Complex to the $T$ Building will place these operations in a safer, state-of-the-art glovebox systems. Through the utilization of modern laboratory equipment and enhanced containment, the project will reduce the quantity of routine airborne tritium releases and volume of solid tritiated wastes resulting from routine PE/PD laboratory operations. The increased reliance placed on engineered safety aspects and stronger mitigative measures by the project will also reduce the risk associated with these operations by reducing both the probability and consequences of unusual occurrences involving uncontrolled tritium releases. 


\section{REFERENCES}

1. Final Environmental Impact statement, Mound Facility, Miamisburg, Ohio, DOE/EIS-0014, U.S. Department of Energy (DOE), Washington, DC, June 1979.

2. T. M. Flanagan, "Treatise on the Environmental Impact Resulting from Mound's Technical (T) Building Tritium Operations," EG\&G Mound Applied Technologies, Mound Plant, April 1985.

3. Memorandum from Robert J. Stern, Director, office of Environmental Compliance, U.S. DOE, to Carlos E. Garcia, Director, Environmental, Safety, and Health Division, Albuquerque Operations office/DOE, "NEPA Review: Proposed Mound Technical (T) Building Tritium Operations," July 3, 1985.

4. International Commission on Radiological Protection (ICRP) Publication 30, "Limits for Intakes of Radionuclides by workers."

5. DOE 5400.5, Radiation Protection of the Public and the Environment, U.S. Department of Energy (DOE), Washington, DC, February 1990.

6. Mound Plant Implementation Plan for DOE order 5000.3A, occurrence Reporting and Processing of Operations Information, EG\&G Mound Applied Technologies, Mound Plant, September 1990.

7. MLM-CF-83-11-1, "Final Safety Analysis Report for the Technical (T) Building," Mound Plant, November 1983.

8. MLM-CF-84-11-1, "Preliminary Safety Analysis Report for the Savannah River Operations Contingency (SROC) Program, Mound Plant, November 1984 .

9. MLM-CF-89-11-0067, "Final Safety Analysis Report for the Semi-Works/Research (SW/R) Tritium Complex (U)," Mound Plant, November 1989.

10. MLM-ML-90-45-0001, "Draft Preliminary Safety Analysis Report for the Nuclear Facilities Modernization (NFM) Project at Mound," May 1990.

11. Canfagno, D. G., and Farmer, B. M., "Environmental Monitoring at Mound: 1989 Report," MLM-3634, EG\&G Mound Applied Technologies, Mound Plant, June 1990. 
12. T. M. Flanagan, "Technical Assessment of Mound's 1987 Occupational Tritium Effective Dose Equivalents, " EG\&G Mound Applied Technologies, Mound Plant, February 1988.

13. T. M. Flanagan, "Technical Assessment of Mound's 1988 Tritium Occupational Effective Dose equivalents and the As Low As Reasonably Achievable (ALARA) Program," EG\&G Mound Applied Technologies, Mound Plant, March 1989.

14. Loss Prevention and Environmental Control Technical Manual, MD-10193, Revision No. 4, EG\&G Mound Applied Technologies, Mound Plant, December 1990.

\section{DISCLAIMER}

This report was prepared as an account of work sponsored by an agency of the United States Government. Neither the United States Government nor any agency thereof, nor any of their employees, makes any warranty, express or implied, or assumes any legal liability or responsibility for the accuracy, completeness, or usefulness of any information, apparatus, product, or process disclosed, or represents that its use would not infringe privately owned rights. Reference herein to any specific commercial product, process, or service by trade name, trademark, manufacturer, or otherwise does not necessarily constitute or imply its endorsement, recommendation, or favoring by the United States Government or any agency thereof. The views and opinions of authors expressed herein do not necessarily state or reflect those of the United States Government or any agency thereof. 